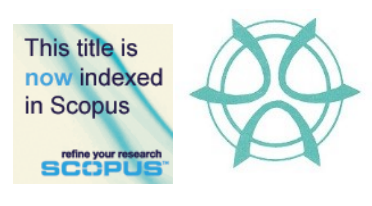

\title{
DECISION MAKING PRINCIPLES IN LAND DEVELOPMENT APPROVAL
}

\author{
Suhailizan Suliman ${ }^{1}$, Salfarina Samsudin ${ }^{2}$, Mohd Hamdan Ahmad ${ }^{3}$ \\ ${ }^{1,2,3}$ Faculty of Built Environment and Surveying \\ UNIVERSITI TEKNOLOGI MALAYSIA
}

\begin{abstract}
The inconsistency of legal coordination is one of the contributing factors in land use conflict. This scenario implicates various objections to the court due to the dissatisfaction of the landowners and developers with the decision of land development approval. In Malaysia, studies about land use conflict in land development conducted by previous researchers only cater on conflict factors and not in the perspective of its operational approach by the stakeholder. Therefore, this paper aims to identify the decision-making principles for decision-makers in grant land development approval. This paper adopts qualitative methods that consist of two types of data collection. The first method used was desk study analysis of ten (10) file cases of development application and the second method involved is an in-depth interview with selected respondents. The result from the analysis of ten (10) file cases determined the decision-making trends that were then cross-tabulated with the five principles of decision-making by using an indepth interview with the selected respondents. The result from the analysis indicates five principles of decision-making which is intuition, rational, authority, factual, and experience. The findings of this paper contribute towards the aspects of strategic decision-making, decision-maker practices, and further research. A comprehensive decision-making principle will then minimise the risk of fallacy in decision-making.
\end{abstract}

Keywords: Land Use Conflict, Land Development Approval, Decision-Making

\footnotetext{
${ }^{1}$ PhD Candidate at Universiti Teknologi Malaysia Email: suhailizan@johor.gov.my
} 
Suhailizan Suliman, Salfarina Samsudin, Mohd Hamdan Ahmad

Decision Making Principles in Land Development Approval

\section{INTRODUCTION}

A development project is bound by legislation that has been set to ensure that any kind of development is carried out in a planned manner without creating turbulence to the community and the current land use planning. The law is fundamental in mobilising the function of a society as an agent of development, where the philosophy of its formation is aimed to provide guidelines and regulations of society appropriate behaviour. Based on Article 172 of the Federal Constitution 1957, the separation of powers principles have created rules in various fields including the aspects of land administration and development (Chun, J. Hai @ Ibrahim \& Nor Fadzlina Nawi, 2012). Land matters are the jurisdiction of the state government as enacted in Article 74, and List 2 of the State List, Federal Constitution 1957. However, Article 76 (4) specifically empowers the Federal Government through Parliament to formulate laws that are relating to land matters for legal coordination (Yusof, MF, 2016). The enactment of this legislation includes the National Land Code 1965, Town and Country Planning Act 1976, Land Acquisition Act 1984, Strata Titles Act 1985, Local Government Act 1976, Roads, Drainage and Buildings Act 1974 and others. The coordination of the enacted law serves to support and codify the land matters for the national development agenda and can be realised besides the application of controlling and monitoring elements.

In peninsular Malaysia, the State Government is fully responsible for land matters. The jurisdiction of the land administration is divided according to districts level and special areas. Simultaneously for each district level, matters regarding land development jurisdiction have been given to the Local Authority. The local authority is responsible for development planning as it means that any development application must obtain planning permission from them. The local authority needs to ensure that any development application abides by the legislation, plans and regulations such as building laws, zoning, and land use planning. The local authority should also ensure compliance to section 120 of the NLC pertaining to land use conditions that is imposed by the State Authority in determining development approval. This scenario has created conflict in determining land use between planning contexts through planning guidelines under the Town and Country Planning Act (Act 172) as well as land use conditions on the document title as enacted under the National Land Code, 1965.

\section{RESEARCH BACKGROUND}

Land development activity is a complex process that is implemented by taking into account the various needs and desires of individuals, communities and stakeholders. Act 172 defines land development as carrying out building, engineering, mining works or changing the type of land use or building or subdivision of land boundaries and land consolidation. In other words, land development refers to the conversion of land from one use to another for various 
PLANNING MALAYSIA

Journal of the Malaysia Institute of Planners (2021)

purposes such as residential, commercial and industrial. This coincides with the definition by Cunningham, C. R. (2007); as well as Healey, P. \& Barrett, S. M. (1990) that land development refers to any material change of land in the form of a building or site for various activities. However, the land-use change process needs to be well controlled through the existing regulations.

Theoretically, the enactment of the National Land Code (NLC) 1965 was made based on the context of land management and administration which is translated under the jurisdiction of the state. The purpose of land management and administration is not only to provide a medium for infrastructure development but also to indirectly hold the concept of income generation for the state government. Accordingly, the Town and Country Planning Act 1976 (Act 172) was enacted for the purpose of planning and controlling the current and future development.

The provisions of NLC 1965 and TCPA 1976 (Act 172) have their own respective interests in terms of planning and land development activities. The overlap in applicable legislation causes the violation of land use conditions that will directly affect the various parties, especially landowners and the state government. This scenario coincides with the statement of INSTUN (2007) which stated that conflict will occur due to the inconsistency of coordination of the legislation and authorities who are responsible for planning and controlling the development. Land use conflict arises in the land development approval process that causes stunted land development. This conflict was identified when there were variations of technical reviews by planners, namely PLANMalaysia and the Local Planning Authority, which contradicted the recommendation from the Land Office and the prepared paperwork from the State Land and Mines Office that had been brought to the State Authority for final approval. Hence, while technical reviews are very important in assisting the State Authority in deciding the final approval of the development application, the decision-making trend should be examined in determining the principle of decision making among the decision-makers.

\section{LITERATURE REVIEW}

\section{Land Development Approval Process}

Land development application shall be submitted to the local planning authority to enable the issuance of the planning permission before the commencement of any land development activity, with the exception of permitted development as enacted under section 19 (2). The necessity of planning permission in section 19 (1) of the Town and Country Planning Act (Act 172) was emphasised as mandatory. The failure to comply with the planning permission requirements may incur a penalty under section 27 and 28 of Act 172 . 
Suhailizan Suliman, Salfarina Samsudin, Mohd Hamdan Ahmad

Decision Making Principles in Land Development Approval

Land development application in Malaysia is based on five categories as enacted under NLC 1965, they are; land conversion (Section 124A), subdivision (Section 135), amalgamation (Section 146), and surrender and realienation (Section 203 and Section 204A-H). Land Development Application is based on categories or the single application can be submitted directly to the land office, while an application that is based on the special provision under section 203 and 204A-H (Surrender and Re-Alienation (SBBS) must require planning permission through the One-Stop Centre (OSC) at the local planning authority.

Contrariwise with the current practice, the state of Johor has implemented a slightly different approach. Land development application in Johor can be submitted based on a single application through section 124 (land conversion) and is based on the special provision under section 197/200 crossrefer to section 76 (Surrender and Re-Alienation (SBKS)). Land development application through a single application includes the process of SBKS without requiring planning permission. However, land development application through SBKS requires planning permission before the SBKS submission. As in any land development application that requires planning permission, the application must be submitted to the local planning authority in order for them to process it through the One Stop Centre, the One-Stop Centre coordinates technical agencies in land development to provide technical reviews on a development application that enables concurrent development approvals. It allows applications to be submitted simultaneously to the required technical agencies especially the District Land Office and the Local Planning Authority. The concept of technical agencies integrations in the One-Stop Centre enables an effective service delivery system in land development.

\section{Conflict of Land Use}

The impact of land-use change has raised several issues (Petit CC, 2002; Christopoulou et al. 2007; Jomaa et al, 2008; Paul \& Tonts, 2005). Section 5 of the NLC 1965 provides that alienated land is any land under that is under a registered title that has been granted by State Authority based on certain conditions or that has been given based on any land legislation in force. In granting the land ownership, the State Authority must first determine the area of land, tenure, type of title, annual tax rate, premium rate, land use category, express conditions and the restrictions of interest on the land. Once the land is successfully registered to the landowner, the title is guaranteed by the State Authority through section 340 (Indefeasibility of Title) NLC 1965. This means that the landowners can maximise the use of the land by complying with the land conditions that have been imposed on the land, based on section 120 NLC 1965 which must be cross-referred with sections 115, 116 and 117 NLC 1965. If the owner wants to carry out development that does not coincide with the conditions 
of the land that is gazetted by the State Authority, the owner can apply for a variation of condition (section 124 A) through a direct application or a simultaneous application through Surrender and Re-Alienation as provided in section 203 and $204 \mathrm{~A}-\mathrm{H}$ and section 197, cross-refer to section 76 as implemented in the State of Johor

Although, NLC 1965 has stated that land ownership belongs to certain landowners but the development on such lands are bound by a plan that has been made at the local level (Syazlina, 2019). The provision of subsection 22 (3) of Act 172 clarifies the statement that the local planning authority can approve or refuse to grant planning permission and that its consideration is subjected to the gazetted Local Plan (LP). This means that the land development must also take into account the aspects of planning at the local authority level as in the Town and Country Planning Act 1976 (Act 172), which has been enacted as a more comprehensive land use development control measure.

In the current practice, land-use conflicts arise when the Local Authorities rejects the planning permission of certain application due to the failure of the proposed development plan to comply with the zoning requirements as per the Local Plan. However, this contradicts with the recommendations from the land office and paperwork from the Land and Mines Office that will influence the final decision that is made by the State Authority. Due to the planning authority's rigidness in granting planning permission that is based on gazetted zoning, the land administrator will give its recommendations based on the compliance to the express and implied condition of the land title as enacted under the NLC 1965. These two documents are deemed to be inconsistent in the aspect of approving land development applications which have been proven to have a direct impact on landowners, investors, and also the stakeholders. The difference of resolution between the two sources of legislative power must be dynamic to ensure that the objectives of development fulfil the needs of the society.

\section{Decision-Making in Land Development Approval}

Conflict can be a catalyst for improvement in land governance and prevents bureaucratic routine (Forester, 2013: Griggs et al, 2014; Paoli, 2008). To avoid or minimise conflict, good decision making is crucial. Decision-making is an intellectual process that involves a selection of one course of action out of many alternatives. Decision-making involves the selection of a course of action from among two or more possible alternatives in order to solve a given problem (Suraj Panpatte, V.D Takale, 2019). The main functions of decision-making in the public sector are to deliver excellent service to society (Bercu, 2013). Dillon et. al. (2010) stated that the process of decision-making in the public sector starts with vague objectives and goals, which are then followed by searching for the alternatives and solutions to accomplish it. Typically, decision-making in the public sector is related to various conflicts, the controversial and high influence 
Suhailizan Suliman, Salfarina Samsudin, Mohd Hamdan Ahmad

Decision Making Principles in Land Development Approval

of external factors (Ring \& Peryy, 1985; Kotler \& Lee, 2007). The public sector has always faced a very complicated and risky decision, political forces, the stakeholders are involved in decision-making which leads to a slow process of making decisions due to the delays, interruption from an outsider, changes in the decision and greater number of formal meetings with various parties in order to make a decision (Nutt, 2005; Kotler \& Lee 2007).In the land development process, decision-making takes place in every phase but the most crucial part is at the stage of the land development approval. Since the land development approval phase is seen as an enabler for the commencement of any land development, the decision-maker who is involved should establish an acumen persona. The land development approval process involves a variety of decisionmakers in each process. Figure 1 illustrates the summary involvement of the said decision-makers.

The illustration in Figure 1 also applies for the single application especially under Section 124 (variation of condition) however; the application is not submitted through the OSC. As single application is submitted directly to the land office, the technical reviews are still needed as aforementioned in the procedures of surrender and re-alienation (SBBS/SBKS). Technical reviews from all agencies will influence the State Authority's decision of approval. This reflects the importance of giving precise technical reviews in accordance to the expertise of their respective fields.

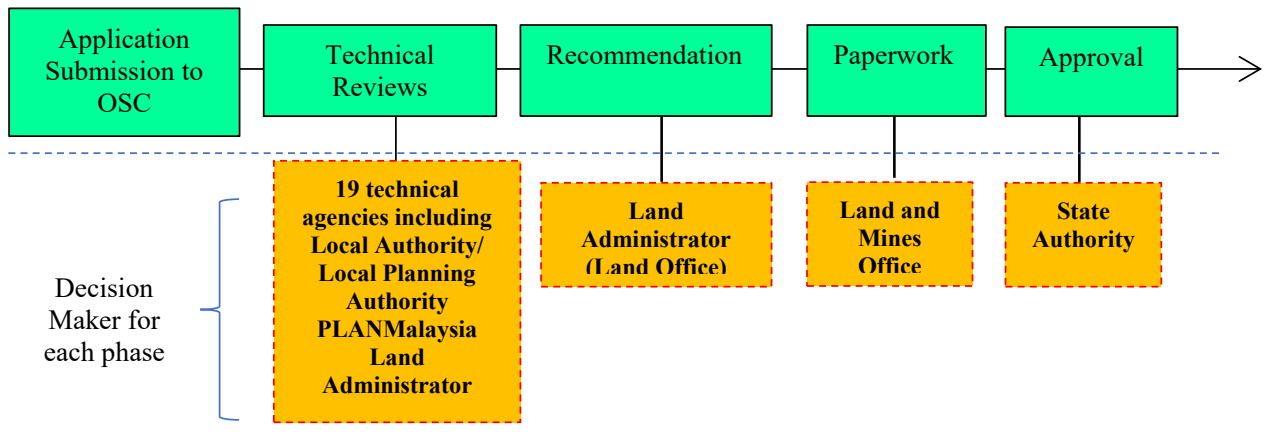

Figure 1: Decision-maker Involvement in Land Development Approval Process

In giving technical reviews, most technical agencies have been provided with general rules or the knowledge as to what to consider and what to look into but the fact is that the decision-making process is not only influenced by the guideline but also other factors such as, rationale factors, physiological factors, social factors and cultural factors (Shahsavarani, A. M., \& Azad Marz Abadi, E., (2015)). Table 1 shows the most significant basis or principles of decision making in general manner based on previous research. According to 
table 1, there is five most significant principles of decision making which are rationale, intuition, facts, experience and authority. These five principles correlate directly and indirectly in the land development decision-making process.

Table 1: Summarisation of Decision-Making Principles by Previous Research

\begin{tabular}{|c|c|c|c|c|c|c|c|}
\hline Authors (Years) & 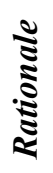 & 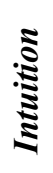 & 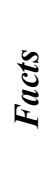 & 彦 & 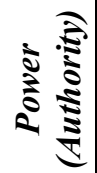 & 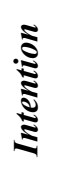 & 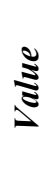 \\
\hline Terry, George R. \& Leslie W. Rue. (2008). & $\mathbf{x}$ & $\mathbf{x}$ & $\mathbf{x}$ & $\mathbf{x}$ & $\mathbf{x}$ & & \\
\hline Harteis, C., \& Billett, S. (2013). & $\mathbf{x}$ & $\mathbf{x}$ & $\mathbf{x}$ & & & & \\
\hline Yechiam, E., \& Aharon, I. (2012) & $\mathbf{x}$ & $\mathbf{x}$ & $\mathbf{x}$ & $\mathbf{x}$ & & & \\
\hline $\begin{array}{l}\text { Shahsavarani, A. M., \& Azad Marz Abadi, } \\
\text { E. (2015) }\end{array}$ & $\mathbf{x}$ & $\mathbf{x}$ & $\mathbf{x}$ & $\mathbf{x}$ & $\mathbf{x}$ & & \\
\hline $\begin{array}{l}\text { Alavi, S. A., Rezaei, S., Valaei, N., \& Wan } \\
\text { Ismail, W. K. (2016). }\end{array}$ & $\mathbf{x}$ & $\mathbf{x}$ & $\mathbf{x}$ & $\mathbf{x}$ & & & \\
\hline Gold, J. I., \& Shadlen, M. N. (2007) & $\mathbf{x}$ & $\mathbf{x}$ & $\mathbf{x}$ & & & $\mathbf{x}$ & $\mathbf{x}$ \\
\hline Amiruddin, M. S., \& Karima, M. K. (2019) & $\mathbf{x}$ & $\mathbf{x}$ & $\mathbf{x}$ & $\mathbf{x}$ & $\mathbf{x}$ & & \\
\hline
\end{tabular}

\section{METHODOLOGY}

As this research is exploratory in nature, the data collection process has been divided into two phases. The first phase involves data collection through case studies. Ten (10) cases of land development applications in Johor have been selected and analysed using the method of content analysis. The selected cases will be coded as $\mathrm{C} 1, \mathrm{C} 2, \mathrm{C} 3, \mathrm{C} 4, \mathrm{C} 5, \mathrm{C} 6, \mathrm{C} 7, \mathrm{C} 8, \mathrm{C} 9$ and $\mathrm{C} 10$. The output from the content analysis determined the decision-making trends in the process of land development approval. The identified trend has been cross-tabulated with the five principles of decision- making which is a continuation of the data collection in phase two. In data collection phase two, the cross-tabulated data was verified using an in-depth interview with selected respondents. Respondents have been selected using purposive sampling. The respondents involved are listed in Table 2. The decision-making trend through case studies are explained and tabulated with the principles of decision-making that have been coded as: Factual (P1), Intuition (P2), Experience (P3), Authority (P4), Rationale (P5) to the respondents in order to capture their perception and justification.

Table 2: List of Selected Respondents

\begin{tabular}{ccccc}
\hline Group & Agencies & $\begin{array}{c}\text { Type of } \\
\text { Respondent }\end{array}$ & $\begin{array}{c}\text { Respondent } \\
\text { Code }\end{array}$ & $\begin{array}{c}\text { No of } \\
\text { Respondent }\end{array}$ \\
\hline 1 & PLANMalaysia & Planners & $\mathrm{R} 1, \mathrm{R} 2, \mathrm{R} 3$ & 3 \\
\hline
\end{tabular}


Suhailizan Suliman, Salfarina Samsudin, Mohd Hamdan Ahmad

Decision Making Principles in Land Development Approval

\begin{tabular}{ccccc}
\hline $\mathbf{2}$ & Local Authority & $\begin{array}{c}\text { Local Planning } \\
\text { Authority } \\
\text { Land }\end{array}$ & R4, R5, R6 & 3 \\
\multirow{3}{*}{4} & District Land Office & $\begin{array}{c}\text { R7, R8, R9 } \\
\text { Administrator } \\
\text { Chief Assistant } \\
\text { Director }\end{array}$ & $\begin{array}{c}\text { R10, R11, } \\
\text { R12 }\end{array}$ & 3 \\
\hline \multicolumn{5}{c}{ Total Respondents } \\
\hline \multicolumn{2}{c}{ Office }
\end{tabular}

The data from the in-depth interview are analysed using the method of descriptive analysis, which has produced a set of principles of decision-making that has been applied by the decision-makers in the process of land development approval. The principles of decision making are then detailed out to find the element that will act as a guideline for the decision-makers in their decisionmaking consideration.

\section{RESEARCH FINDINGS AND ANALYSIS}

\section{Decision Making Trend in Land Development Approval}

The decision-making trend analysis has been identified through content analysis based on the ten (10) case studies of land development application in Johor. The result from the analysis shows a variation of decision-making that has been made by the decision maker. The decision-making trend from the ten (10) cases are summarised as shown in Table 3.

Table 3: Analysis of Decision-Making Trend by Five Agencies for Ten (10) case

\begin{tabular}{|l|c|c|c|c|c|c|c|c|c|c|}
\hline \multicolumn{1}{|c|}{ Case } & C1 & $\mathbf{C 2}$ & $\mathbf{C 3}$ & $\mathbf{C 4}$ & $\mathbf{C 5}$ & $\mathbf{C 6}$ & $\mathbf{C 7}$ & $\mathbf{C 8}$ & $\mathbf{C 9}$ & $\mathbf{C 1 0}$ \\
\hline Agencies & & & & & & & & & & \\
\hline Local Authority & $/$ & $/$ & $\mathbf{x}$ & $/$ & $/$ & $/$ & $\mathbf{x}$ & $/$ & $/$ & $/$ \\
\hline Land Office & $/$ & $/$ & $/$ & $/$ & $/$ & $/$ & $/$ & $/$ & $/$ & $/$ \\
\hline $\begin{array}{l}\text { Land \& Mines } \\
\text { Office }\end{array}$ & $/$ & $/$ & $/$ & $/$ & $/$ & $/$ & $\mathbf{x}$ & $/$ & $/$ & $/$ \\
\hline State Authority & $/$ & $/$ & $/$ & $/$ & $/$ & $/$ & $\mathbf{x}$ & $/$ & $/$ & $/$ \\
\hline
\end{tabular}

Based on the analysis, the variation of decision-making trends has spotted when there is an inconsistency in the decision- making process from the planners for a few cases which are $\mathrm{C} 3$ and $\mathrm{C} 7$. Decision-making by the planners is important because a development application needs to obtain the Planning Permission at this stage before the commencement of the development. The local authority did not agree with the development application because it contradicted the zoning that was stated in the local plan. In the case of $\mathrm{C} 3$, although the local 
authority as the local planning authority did not approve the application, PLANMalaysia justified that the development application can be considered. The decision-making inconsistency in this case shows that the element of the approval consideration does not only refer to the prerequisite local plan, and therefore does not fix the problem.

Justification from the Land Office and the Land and Mines Office stated that the development application should be considered and the land title registration was given before the local plan. At the final stage of the decision making process, the State Authority gave full approval to the development application. In contrast to the case in C7, both PLANMalaysia and the local authority did not approve the development application due to the contradiction with the gazetted zoning and the fact that it was not suitable. However, the land office justified that the development application should be considered. In opposition to that, the Land and Mines Office supported the disapproval of this application as per PLANMalaysia's justification and that the application was rejected by the State Authority. Upon reflection on this, it can be concluded that there are other elements of consideration that are used by the decision-makers in considering an application.

For the cases $\mathrm{C} 1, \mathrm{C} 2, \mathrm{C} 4, \mathrm{C} 5, \mathrm{C} 6, \mathrm{C} 8, \mathrm{C} 9$, and $\mathrm{C} 10$ the decision-making trend was consistent for each agency although there was a conflict between the development applications and the zoning in the local plan. The approval was given based on the discretion of the decision-makers. This indicates a decisionmaking gap which is the determination basis that the decision-makers have applied in considering the approval of a development application.

\section{Decision-Making Principle in Land Development Application}

The decision-making trend analysis in the data collection Stage 1 has been tabulated with the five (5) principles of decision-making in order to validate the decision-makers basis in determining the decision of the development application. Through the interview, the selected respondents were briefed on the ten (10) case studies as well as decision-making trends by the decision-maker. The respondents were asked to select the decision-making principles that were suited with the decision-making trends as seen in the ten (10) cases. In addition, the views from the selected respondents are also taken into account in justifying the selected basis and principle that have been used by the decision-maker in the decision-making consideration. The results are illustrated briefly in Table 4 .

Table 4: Analysis of Decision-Making Principle

\begin{tabular}{|l|l|l|l|l|l|}
\hline Principle & Principle 1 & Principle 2 & Principle 3 & Principle 4 & Principle 5 \\
Case & & & & & \\
\hline
\end{tabular}


Suhailizan Suliman, Salfarina Samsudin, Mohd Hamdan Ahmad

Decision Making Principles in Land Development Approval

\begin{tabular}{|c|c|c|c|c|c|}
\hline C1 & $\begin{array}{l}\text { R1, R2, R3, R4, } \\
\text { R5, R6, R7, R8, } \\
\text { R9, R10, R11, R12 }\end{array}$ & $\begin{array}{l}\text { R1, R2, R3, R4, } \\
\text { R5, R6, R7, R8, } \\
\text { R9, R10, R11, R12 }\end{array}$ & $\begin{array}{l}\text { R1, R2, R3, R4, } \\
\text { R5, R6, R7, R8, } \\
\text { R9, R10, R11, R12 }\end{array}$ & $\begin{array}{l}\text { R1, R2, R3, R4, } \\
\text { R5, R6, R7, R8, } \\
\text { R9, R10, R11, R12 }\end{array}$ & $\begin{array}{l}\text { R1, R2, R3, R4, } \\
\text { R5, R6, R7, R8, } \\
\text { R9, R10, R11, R12 }\end{array}$ \\
\hline $\mathrm{C2}$ & $\begin{array}{l}\text { R1, R2, R3, R4, } \\
\text { R5, R6, R7, R8, } \\
\text { R9, R10, R11, R12 }\end{array}$ & $\begin{array}{l}\text { R1, R2, R3, R4, } \\
\text { R5, R6, R7, R8, } \\
\text { R9, R10, R11, R12 }\end{array}$ & $\begin{array}{l}\text { R1, R2, R3, R4, } \\
\text { R5, R6, R7, R8, } \\
\text { R9, R10, R11, R12 }\end{array}$ & $\begin{array}{l}\text { R1, R2, R3, R4, } \\
\text { R5, R6, R7, R8, } \\
\text { R9, R10, R11, R12 }\end{array}$ & $\begin{array}{l}\text { R1, R2, R3, R4, } \\
\text { R5, R6, R7, R8, } \\
\text { R9, R10, R11, R12 }\end{array}$ \\
\hline C3 & $\begin{array}{l}\text { R1, R2, R3, R4, } \\
\text { R5, R6, R7, R8, } \\
\text { R9, R10, R11, R12 }\end{array}$ & $\begin{array}{l}\text { R1, R2, R3, R4, } \\
\text { R5, R6, R7, R8, } \\
\text { R9, R10, R11, R12 }\end{array}$ & $\begin{array}{l}\text { R1, R2, R3, R4, } \\
\text { R5, R6, R7, R8, } \\
\text { R9, R10, R11, R12 }\end{array}$ & $\begin{array}{l}\text { R1, R2, R3, R4, } \\
\text { R5, R6, R7, R8, } \\
\text { R9, R10, R11, R12 }\end{array}$ & $\begin{array}{l}\text { R1, R2, R3, R4, } \\
\text { R5, R6, R7, R8, } \\
\text { R9, R10, R11, R12 }\end{array}$ \\
\hline C4 & $\begin{array}{l}\text { R1, R2, R3, R4, } \\
\text { R5, R6, R7, R8, } \\
\text { R9, R10, R11, R12 }\end{array}$ & $\begin{array}{l}\text { R1, R2, R3, R4, } \\
\text { R5, R6, R7, R8, } \\
\text { R9, R10, R11, R12 }\end{array}$ & $\begin{array}{l}\text { R1, R2, R3, R4, } \\
\text { R5, R6, R7, R8, } \\
\text { R9, R10, R11, R12 }\end{array}$ & $\begin{array}{l}\text { R1, R2, R3, R4, } \\
\text { R5, R6, R7, R8, } \\
\text { R9, R10, R11, R12 }\end{array}$ & $\begin{array}{l}\text { R1, R2, R3, R4, } \\
\text { R5, R6, R7, R8, } \\
\text { R9, R10, R11, R12 }\end{array}$ \\
\hline $\mathrm{C5}$ & $\begin{array}{l}\text { R1, R2, R3, R4, } \\
\text { R5, R6, R7, R8, } \\
\text { R9, R10, R11, R12 }\end{array}$ & $\begin{array}{l}\text { R1, R2, R3, R4, } \\
\text { R5, R6, R7, R8, } \\
\text { R9, R10, R11, R12 }\end{array}$ & $\begin{array}{l}\text { R1, R2, R3, R4, } \\
\text { R5, R6, R7, R8, } \\
\text { R9, R10, R11, R12 }\end{array}$ & $\begin{array}{l}\text { R1, R2, R3, R4, } \\
\text { R5, R6, R7, R8, } \\
\text { R9, R10, R11, R12 }\end{array}$ & $\begin{array}{l}\text { R1, R2, R3, R4, } \\
\text { R5, R6, R7, R8, } \\
\text { R9, R10, R11, R12 }\end{array}$ \\
\hline C6 & $\begin{array}{l}\text { R1, R2, R3, R4, } \\
\text { R5, R6, R7, R8, } \\
\text { R9, R10, R11, R12 }\end{array}$ & $\begin{array}{l}\text { R1, R2, R3, R4, } \\
\text { R5, R6, R7, R8, } \\
\text { R9, R10, R11, R12 }\end{array}$ & $\begin{array}{l}\text { R1, R2, R3, R4, } \\
\text { R5, R6, R7, R8, } \\
\text { R9, R10, R11, R12 }\end{array}$ & $\begin{array}{l}\text { R1, R2, R3, R4, } \\
\text { R5, R6, R7, R8, } \\
\text { R9, R10, R11, R12 }\end{array}$ & $\begin{array}{l}\text { R1, R2, R3, R4, } \\
\text { R5, R6, R7, R8, } \\
\text { R9, R10, R11, R12 }\end{array}$ \\
\hline C7 & $\begin{array}{l}\text { R1, R2, R3, R4, } \\
\text { R5, R6, R7, R8, } \\
\text { R9, R10, R11, R12 }\end{array}$ & $\begin{array}{l}\text { R1, R2, R3, R4, } \\
\text { R5, R6, R7, R8, } \\
\text { R9, R10, R11, R12 }\end{array}$ & $\begin{array}{l}\text { R1, R2, R3, R4, } \\
\text { R5, R6, R7, R8, } \\
\text { R9, R10, R11, R12 }\end{array}$ & $\begin{array}{l}\text { R1, R2, R3, R4, } \\
\text { R5, R6, R7, R8, } \\
\text { R9, R10, R11, R12 }\end{array}$ & $\begin{array}{l}\text { R1, R2, R3, R4, } \\
\text { R5, R6, R7, R8, } \\
\text { R9, R10, R11, R12 }\end{array}$ \\
\hline C8 & $\begin{array}{l}\text { R1, R2, R3, R4, } \\
\text { R5, R6, R7, R8, } \\
\text { R9, R10, R11, R12 }\end{array}$ & $\begin{array}{l}\text { R1, R2, R3, R4, } \\
\text { R5, R6, R7, R8, } \\
\text { R9, R10, R11, R12 }\end{array}$ & $\begin{array}{l}\text { R1, R2, R3, R4, } \\
\text { R5, R6, R7, R8, } \\
\text { R9, R10, R11, R12 }\end{array}$ & $\begin{array}{l}\text { R1, R2, R3, R4, } \\
\text { R5, R6, R7, R8, } \\
\text { R9, R10, R11, R12 }\end{array}$ & $\begin{array}{l}\text { R1, R2, R3, R4, } \\
\text { R5, R6, R7, R8, } \\
\text { R9, R10, R11, R12 }\end{array}$ \\
\hline C9 & $\begin{array}{l}\text { R1, R2, R3, R4, } \\
\text { R5, R6, R7, R8, } \\
\text { R9, R10, R11, R12 }\end{array}$ & $\begin{array}{l}\text { R1, R2, R3, R4, } \\
\text { R5, R6, R7, R8, } \\
\text { R9, R10, R11, R12 }\end{array}$ & $\begin{array}{l}\text { R1, R2, R3, R4, } \\
\text { R5, R6, R7, R8, } \\
\text { R9, R10, R11, R12 }\end{array}$ & $\begin{array}{l}\text { R1, R2, R3, R4, } \\
\text { R5, R6, R7, R8, } \\
\text { R9, R10, R11, R12 }\end{array}$ & $\begin{array}{l}\text { R1, R2, R3, R4, } \\
\text { R5, R6, R7, R8, } \\
\text { R9, R10, R11, R12 }\end{array}$ \\
\hline C10 & $\begin{array}{l}\text { R1, R2, R3, R4, } \\
\text { R5, R6, R7, R8, } \\
\text { R9, R10, R11, R12 }\end{array}$ & $\begin{array}{l}\text { R1, R2, R3, R4, } \\
\text { R5, R6, R7, R8, } \\
\text { R9, R10, R11, R12 }\end{array}$ & $\begin{array}{l}\text { R1, R2, R3, R4, } \\
\text { R5, R6, R7, R8, } \\
\text { R9, R10, R11, R12 }\end{array}$ & $\begin{array}{l}\text { R1, R2, R3, R4, } \\
\text { R5, R6, R7, R8, } \\
\text { R9, R10, R11, R12 }\end{array}$ & $\begin{array}{l}\text { R1, R2, R3, R4, } \\
\text { R5, R6, R7, R8, } \\
\text { R9, R10, R11, R12 }\end{array}$ \\
\hline
\end{tabular}

The results from the analysis showed that all the respondents were in agreement that the five (5) principles of decision-making were applied in the development application approval. The five principles mentioned are Factual (P1), Intuition (P2), Experience (P3), Authority (P4), and Rationale (P5).

\section{Factual (P1)}

All respondents agreed that the factual is the principle of decision-making that must be applied by decision-makers. Decision-makers should know and investigate the facts of case before any decision is made. When the development application is submitted to the OSC to get a review from the technical department, R1, R2, R3, R4, R6 have stated that the decision-maker should identify the zoning of the area and the current development on the land plan. R5, R7, R8, R9, R10, R11 and R12 stated that the land background should also take into account the basis for its alienation, physical or non-physical encumbering event to the extent of what was already built on the land, title registration date and land category (express condition and implied condition). Thus, it can be summarised that decision-makers in land development applications should take into account the element of zoning, current development on the land and the background of the land before any decision is made. This element will help decision-makers in good decision-making. Decision-making that is based on facts is more secured in judgement and will achieve better performance than others. 
PLANNING MALAYSIA

Journal of the Malaysia Institute of Planners (2021)

\section{Intuition (P2)}

Decision-making based on intuition is subjective and vulnerable. However, decisions made through intuition are provided by knowledge that is stored in the long-term memory that has been primarily acquired through associative learning. The input will be processed automatically and without conscious awareness. The results from the analysis shows that all the respondents have agreed that decisions that have been made on the ten (10) cases also influenced by intuition. The basis of intuition in the development application decision is divided into three categories which are affective, cognitive and behavioural intuition. Respondents R1, R2, R3, R4, R5, R6, R7, R8, R9, 10, R11, and R12 agreed that the sense of responsibility had influenced the type of decision. Other than that, respondents $\mathrm{R} 9, \mathrm{R} 10, \mathrm{R} 11$ and R12 also stated that positive thinking helped the decisionmaker in good decision- making. Respondents R7 and R8 have also justified that decisions that have been made through intuition can help the decision-maker to reflect and visualise the development application and decisions that will be made. The action of the decision-makers in referring to an authoritative level in order to get a clearer picture, or perspectives of an expert on the development application is driven by intuition. This statement was agreed by respondents R1, R2, R3, R4, and R5. Respondents R1, R2, R3, R4, R5, R7, R8, R9, R10, R11, and R12 agreed that the decision-makers cannot be biased when giving an approval based on the background of the applicant which reflected behavioural intuition.

\section{Experience (P3)}

Analysis from the tabulated data shows that, all the respondents have agreed that experience will influence the type of decision-making that is made in the land development application. All the respondents have agreed that the more experienced the decision-makers in their agencies are the more literate they will be in considering the development application decision. Thus, the decisionmakers experience can help in predicting the state of things and in anticipating the impact of the decision that is made.

\section{Authority(P4)}

The result from the analysis shows that all the respondents have agreed that power directly influences the decision-making trend. According to the perspectives of decision making in the land development application, the principle of authority can be influenced by the position of the decision-makers in the agency, the level of education as well as the level of authority. This influencing factor is agreed by all the respondents. R1, R5, R7, R9 have stated that in deciding the approval of the development plan, decision-makers sometimes need to refer to the experts and cross-reference with other agencies in gaining more information about a development application. In approving the development applications, sometimes 
Suhailizan Suliman, Salfarina Samsudin, Mohd Hamdan Ahmad

Decision Making Principles in Land Development Approval

they cannot be limited and restricted to be based only on the scope of the power of the decision-makers.

\section{Rationale (P5)}

Rationale is crucial in decision making since decision making in land development approval does not have specific guidelines. Based on the analysis, all the respondents have agreed that the rationality of the decision-maker is important in approving or rejecting the development application. R1, R2, R3 and R4 stated that the decision-makers should focus on problem-solving as a whole, while R5, R6, R10, R11 and R12 emphasised that the rationality of the decisionmakers should include the implementation of relevant legislation with dynamic action besides the focus on fixed legislation.

To sum up the results from the analysis there are five (5) principles of decision-making that must be applied by the decision-makers in approving or rejecting a development application. The result from the analysis is summarised in Table 5.

Table 5: Summary of five decision making principles in land development approval

\begin{tabular}{|c|c|}
\hline Principle of Decision Making & Elements \\
\hline Factual & $\begin{array}{l}\text { - Zoning } \\
\text { - Current development on the land } \\
\text { - Land background }\end{array}$ \\
\hline Intuition & $\begin{array}{l}\text { - Feeling of responsibility, } \\
\text { - Positive thinking, } \\
\text { - Reflect and visualisation of the application } \\
\text { and decision } \\
\text { - Refer to authoritative level } \\
\text { - Un-bias in processing development } \\
\text { application }\end{array}$ \\
\hline Experience & $\begin{array}{l}\text { - Years of experience in the job position } \\
\text { - Years of experience in decision making }\end{array}$ \\
\hline Authority & $\begin{array}{l}\text { - Position of the decision maker in the agency } \\
\text { - Level of education and level of authority }\end{array}$ \\
\hline Rationale & $\begin{array}{l}\text { - Focus on problem solving as a whole } \\
\text { - Implementation of relevant legislation with } \\
\text { dynamic action }\end{array}$ \\
\hline
\end{tabular}

\section{CONCLUSION}

Decision making in land development approval is a set of decision that results from the interaction and integration of various agencies. Decision-makers are responsible for the outcomes that are consonant with their system and organisational objectives. The different types of decision-making pattern which 
cross-culturally can create conflict, in the context of land development approval, thus necessitate the decision-makers who are involved to strive for a mutually acceptable solution despite possessing different values, personality and organisational background. In line with the goals of decision making in land development approval, the five basic principles that have been detailed out the element can serve as a guide for decision-makers in the future.

\section{REFERENCES}

Amiruddin, M. S., \& Karima, M. K. (2019). Decision Making: Effective Basic Leadership. In International Conference on Islamic Educational Management (ICIEM) (Vol. 1, No. 1).

Alavi, S. A., Rezaei, S., Valaei, N., \& Wan Ismail, W. K. (2016). Examining shopping mall consumer decision-making styles, satisfaction and purchase intention. The International Review of Retail, Distribution and Consumer Research, 26(3), 272303.

Bercu, A.M. (2013). Strategic decision making in public sector: Evidence and implications. Economica, 9(1): 21-27.

Chun, J. Hai@ Ibrahim, \& Nor Fadzlina Nawi. (2012). Principles of Public Administration: Malaysian Perspectives.

Cunningham, C. R. (2007). Growth controls, real options, and land development. The Review of Economics and Statistics, 89(2), 343-358.

Christopoulou, O., Polyzos, S., \& Minetos, D. (2007). Peri-urban and urban forests in Greece: obstacle or advantage to urban development? Management of Environmental Quality: An International Journal.

Forester, J. (2013). On the theory and practice of critical pragmatism: Deliberative practice and creative negotiations. Planning theory, 12(1), 5-22.

Griggs S, Norval AJ, Wagenaar H (2014) Practices of Freedom. Decentred Governance, Conflict and Democratic Participation. Cambridge University Press

Gold, J. I., \& Shadlen, M. N. (2007). The neural basis of decision making. Annu. Rev. Neurosci., 30, 535-574.

Paoli JC (2008) Typologie des conflits sur l'espace en fonction des institutions regulatrices: essai sur unechantillon relate par la presse quotidienne regionale en corse. In: Kirat T, Torre A (eds) Territoires de conflits Analyses des mutations de l'occupation de l'espace. L'Harmattan

Panpatte, S., \& Takale, V. D. (2019). To study the decision-making process in an organization for its effectiveness. The International Journal of Business Management and Technology, 3(1), 73-78.

Yusoff, S. M., Yusof, F., \& Arshad, A. F. (2014). An analysis of local plan for development control at local planning level in the state of Selangor. ProcediaSocial and Behavioral Sciences, 153, 574-584.

Healey, P., \& Barrett, S. M. (1990). Structure and agency in land and property development processes: some ideas for research. Urban studies, 27(1), 89-103.

Harteis, C., \& Billett, S. (2013). Intuitive expertise: Theories and empirical evidence. Educational research review, 9, 145-157. 
Suhailizan Suliman, Salfarina Samsudin, Mohd Hamdan Ahmad

Decision Making Principles in Land Development Approval

INSTUN (2007) Peranan Pihak Berkuasa Perancang Tempatan Dalam Pembangunan Tanah Kursus Perundangan Dan Pentadbiran Tanah

Jomaa, I., Auda, Y., Saleh, B. A., Hamzé, M., \& Safi, S. (2008). Landscape spatial dynamics over 38 years under natural and anthropogenic pressures in Mount Lebanon. Landscape and urban planning, 87(1), 67-75.

Kotler, P. and N.R. Lee (2007). Marketing in the public sector: The final frontier. Public Manager, 36(1): 12-17

Nutt, P.C. (2005). Comparing public and private sector decision-making practices. Journal of Public Administration Research and Theory, 16(2): 289-318

Petit, C. C., \& Lambin, E. F. (2002). Long-term land-cover changes in the Belgian Ardennes (1775-1929): model-based reconstruction vs. historical maps. Global Change Biology, 8(7), 616-630.

Paül, V., \& Tonts, M. (2005). Containing urban sprawl: trends in land use and spatial planning in the metropolitan region of Barcelona. Journal of Environmental Planning and Management, 48(1), 7-35.

Ring, P. and J. Perry (1985). Strategic management in public and private organizations: Implications of distinctive contexts and constraints.

Academy of Management Review, 10(2): 276-286.

Syazlina (2019) Mekanisme Pelaksanaan Rancangan Tempatan Pengubahan Pihak Berkuasa Perancang Tempatan Negeri Perak. Tesis Sarjana, Fakulti Alam Bina dan Ukur, Universiti Teknologi Malaysia

Shahsavarani, A. M., \& Azad Marz Abadi, E. (2015). The Bases, Principles, and Methods of Decision-Making: a review of literature. International Journal of Medical Reviews, 2(1), 214-225

Terry, G. R.\& Rue, L. W (2008). Principles of Management. Homewood, Illinois: Richard D. Irwin.

Yechiam, E., \& Aharon, I. (2012). Experience-based decisions and brain activity: three new gaps and partial answers. Frontiers in psychology, 2, 390.

Perlembagaan Persekutuan Malaysia

Kanun Tanah Negara 1965 (Akta 56/1965)

Akta Perancangan Bandar dan Desa 1972 (Akta 172)

Received: $19^{\text {th }}$ August 2021. Accepted: $25^{\text {th }}$ November 2021 